Živko Mikić

Belgrade University, The Faculty of Philosophy, Department of Archaeology, Belgrade
UDK 904:572.72"653"(497.11)

902.2(497.11)"190"

Original research article

Received: January 15, 2010

Accepted: August 02, 2010

\title{
TREPANNING ON MEDIAEVAL GAMZIGRAD - FELIX ROMULIANA
}

\begin{abstract}
Between 1974 and 1992 in Gamzigrad, three locations with mediaeval skeletal burials were archaeologically investigated. More precisely, between 1974 and 1980, within the defence system, most likely near the church, 28 graves were excavated. Eleven skeletons were appropriate for an anthropological analysis. Later on, in 1984, near the southern wall, another three skeletal graves were unearthed and anthropologically investigated. Finally, between 1981 and 1992, the necropolis outside the eastern gate, consisting of 95 skeletons, was fully investigated, both archaeologically and anthropologically. The skeleton no. 28 belonged to a male, up to 45 years of age. On the central part of his left parietal bone, there is a clear mark of a soundly healed trepanning openning, measuring $2 \times 3 \mathrm{~cm}$. The trepanning itself was done in an old technique of filing.

The anthropological analysis of all the skeletons, dating from the 10th and 11th century, was done during 1992.

KEY WORDS: GENDER ANALYSIS, INDIVIDUAL AGE, CHRONOLOGICAL DETERMINATION, ANTHROPOLOGICAL MEASURES, TREPANNING TECHNIQUE, TREPANNING INSTRUMENTS.
\end{abstract}

As already stated in the abstract, the anthropological analysis of human skeletal remains was done in 1992, after the archaeological excavation of the cemetary outside the eastern Gamzigrad gate was finished. That means that the most recent methods of bio-physical anthropology were applied on all the analysis levels. Determination of gender and individual age were done according to the reccomendations of European anthropologists, systematized by D. Ferembach, I. Sch- widetzky and M. Stloukal (1980), also signed by the author of this paper.

All the anthropological measures on adults, on skulls as well as on post-cranial skeletons, were taken according to the methodological rules defined by R. Martin (Martin R. and Seller K., 1957). All the skull indexes were measured and categorized according to the same anthropological criteria. Measuring of height was done according to regression table of long bones of post-cranial

* The article results from the project: Viminacium, Roman city and military legion camp - research of material and non material of inhabitants by using the modern technologies of remote detection, geophysics, GIS, digitalisation and $3 D$ visualisation (no 47018), funded by Ministry of Education and Science of the Republic of Serbia. 
skeletons, made by E. Breitinger (1937) for males and $\mathrm{H}$. Bach (1965) for females and which, after author's experience, correspond best with European skeletal series.

For paleo-pathological diagnoses, case categorizations were used, shown by A. Lovrinčević and Ž. Mikić (1989) and E. Hošovski and Ž. Mikić (1995).

The same methodological criteria were applied on eleven skeletons discovered within the defense wall, most likely near the church, were concerned, as well as on three skeletons discovered near the eastern wall, although they will not be included in this study.

The highlight of this anthropological study is a male skull no. 28 from the cemetery outside the eastern Gamzigrad gate, which was fully archaeologically excavated and anthropologically investigated. It was previously not published, because the intention was to include the latest human osteological material from the sites within the city walls. The intention was also to compare and observe events on the mediaeval Gamzigrad.

\section{$* * *$}

Today, as the only anthropological complex from Gamzigrad - Felix Romuliana, there is the mediaeval cemetery outside the eastern gate, whose paleo-demographical content was recently published (Mikić 2009). Among other data, one could find out that 91 graves were archaeologically excavated with 95 individual skeletons. Still, only 92 skeletons could have undergone an anthropological analysis. There were 31 male skeletons, 31 female skeletons and 30 infants.

As picture 1 shows, the anthropological distribution of skeletons regarding their orientation is a common one, while their disposition i.e. concentration is uneven. On one hand, it follows the architecture of the eastern gate and on the other the slope and consistence of the terrain. As for division according to sex and age, the same conclusion can be repeated - it is mostly an uneven disposition.

Diagramme 1 graphically shows average life lengths.

More precisely, an average life length of men was over 42 years, while women lived a little shorter, between 39 and 40 years of age. It shows that an average adult lived for 41 years. Still, life length of children was rather short. It barely went over five years of age. An average life in this mediaeval population group from Gamzigrad did not exceed 30 years $(29,72)$.

The skull with trepanning (specifically marked on the plan 1 and on diagramme 1) is certain to have belonged to a male individual. Its individual age was less than 45 years. That indicates that this trepanated person easily underwent this very complicated chirurgic operation, even after criteria of modern neuro-chirurgy. It lived longer than an average man did, an average adult or even an average person from the population group examined.

In the anthropological appendix about trepanning in the 20th century in Serbia (Mikić, 2007), the author wrote only a few sentences (without illustrations) about skull no. 28 from Gamzigrad. More precisely, he stated that it belonged to a male individual, who has less that 45 years of age when he died, that the trepanning was located on the left side and that it was succesfully made (according to the osteoplastic reaction of the bone). On the other hand, it was stated that this skull will be published in more details within the publication about the whole necropolis. It can be seen from the title of this paper, since one is dealing with the only trepanated skull from the mediaeval necropolis of Gamzigrad.

Within the whole of the necropolis discovered outside the eastern Gamzigrad gate, i.e. the population which was using it, according to its anthropo-morphological profilation, the trepanated male skull no. 28 fits in the morpho-structure of male individuals. According to tables 1 and 2, in which osteometric data for all of the 15 preserved (11 male and 4 female) skulls were given, it does not exceed any of the average values. For example, the average value of the length-width index is 73,10 . On the trepanated skull no. 28 , this index measures 71,20 , showing that it belongs to the dolichocrane category.

Speaking about corporal height, with eleven male skeletons measured, it was about $168 \mathrm{~cm}$ $(168,23)$, with a variation span from 164 to 177 $\mathrm{cm}$. According to to the anthropological criteria applied in this analysis, the male individual no. 28 was $165 \mathrm{~cm}$ tall. It turnes out that he was among 
the less tall members of the mediaeval population of Gamzigrad.

The features of female members of the population will not be discussed here, especially because, due to their poor state of preservation, only four skeletons were adequate for anthropological measurings. Still, their osteomethrical values for skulls, as well as for post-cranial skeletons, can be seen in tables 1 and 2.

$$
* * *
$$

In the previous chapter, all of the better preserved skulls, including their long bones of the post-cranial skeletons, were in detail osteometrically presented on tables 1 and 2, paleo-demographically on diagramme 1 , as well as on plan 1. The reason for this is that, within the whole of the population group burried outside the eastern Gamzigrad gate, whose necropolis was fully archaeologically investigated, only one trepanated skull was discovered. This situation indicates that it should be observed within the group it belongs to and which dwelt in Gamzigrad during a certain period of time.

One should stress that trepanning is the oldest chirurgic intervention on man's head/skull, which left its traces through time - instruments for trepanning and trepanated skulls themselves. So far known, trepanning first appears in Hypocrat's notes. In his chapter about the head, it was described to the detail and the most important part of the medical intrumentaria was a knife - file and a jagged tubular drill. Since in Europe trepanated skulls appeared much earlier than technology of metal processing, one shuld most certainly think of similar tools made of stone.

In Europe, more precisely in 1973, on a congress "Association française pour l'avancement de la science", P. Prunières showed a skull found in 1868 in a dolmen by Aiguieres (Lozère), along with a bone plate taken from the skull. It is considered the first time when it was pointed out to the existence of prehistoric trepanning.

Further information about trepanning were gained in 1876, at the "International congress for anthropology and prehistoric archaeology" held in Budapest. On that occasion, within his lecture titled "Sur la trépanation du crane et les amulettes cranienne à l' epoque néolithique" P. Bro- ca published results of his voluminous study. $\mathrm{He}$ showed a great number of trepanated skulls and bone rondells, being the first to introduce terms like "trépanation posthume" and "trépanation chirurgicale". He also imposed the problem of osteoplastic reaction of the bone along the edges of the trepanning opening as the main criterium for patient's surviving of this complicated intervention, even according to modern criteria.

After Prunières and Broca, many experts dealt with the problem of trepanated skulls, trying to discover also the motives of its performance. Less than a century later, in 1940, St. Piggott published a list of about two hundred finds and in 1960, P. Hein added 334 skulls to this list. In Europe, several thousands of trepanated skulls were gathered and studied. Their number varies from period to period and also from region to region. Only in Hungary, trepanated skulls come from fifty different sites (Nemeskéri 1960).

From the area of the Middle Balkans, actualy from Serbia, according to results gained so far, the oldest trepanated skulls appear during the Bronze Age and up to the period between 19th and 20th century. They were found on the cemeteries of the Metal Ages in Mokrin and Kriva reka in the Drina valley, on Roman Viminacium and on mediaeval sites like Davidovica and Gamzigrad. Oral data from our archaeologists, that they often encountered trepanated skulls on mediaeval sites, especially in Vojvodina, could have not been proved. Still, the publication of S. Trojanović from 1900, titled "Die Trepanationen bei denSerben ein ethnologischer Beitrag" and pulished in $\mathrm{Mu}-$ nich, brought encyclopedic data: direct oral data, names of trepanated people, places of their burials and a commet that their skulls should be studies when science improves, detailed descriptions of trepanning itself (named "šaronjanje"), description of all the instruments used, postoperative recovering etc. He concluded that then, in 1900, almost nothing is known about trepanning by Serbs and Albanians in Europe, while the same operations by non-European nations are quite well known.

In 1922, S. Trojanović published another paper about trepanning in Skopje, entitled "Šaronjanje kod Srba - novi podaci (Trepanning by Serbs - new data)". This paper mostly repeats what was already published in Munich, conclu- 
ding that folk/village doctors of that time in Hercegovina, Montenegro, Albania and South Serbia practice trepanning, i.e. "šaronjanje" as a usual routine procedure. He also listed personal names of people operated.

In this very brief description of research of the phenomenon of trepanated skulls, beside S. Trojanović, one should mention two further authors:

V. Đorđević was a doctor, educated in Germany, and in 1883 in Berlin he published a study about the development of medical care from 12th to the end of 19th century in Serbia, in which he only mentioned trepanning. The beginning of research of this phenomenon should $b$ brought in connection with S. Trojanović, the first Serbian educated anthropologyst and with the year 1900 .

Much later, in 1948, M. Barjaktarović published a work in Cetinje about "Šaronjanje in Montenegro". One can immediately notice that Trojanović's works from 1900 and 1922 make most of his work. The author also notices that the name "Serbs" and "by Serbs" does not appear in the whole paper. On the other hand, three other data appear: in 1930, a man named Niko Spahov Dučić, a trepanated man from Kuč, died at the age of 80. Further on, in 1928, a famous trepanator from Kuč, Radosav Petrov died, for whose father stories are told that he trepanated about three hundred people. The third data concearns the most famous "doctors". They were the Iličković family from Crmnica, whose complete chirurgic intrumentarium, made by village smiths, is being kept at the Museum of chirurgical clinic of the Medical Univeristy in Moscow ever since 1907 (after Iličković 1940).

In this short historical overview one should stress that at the territory of Serbia, either from preistoric or from historic times, no trepanning instruments were found by archaeologists, so we only have their descriptions from the late 19th and early 20 th century.

After a huge break, Hungarian anthropologists (Farkas and Lipkak 1971) return to the phenomenon of trepanning by publishing a Bronze Age cemetery discovered in Mokrin and on which, according to their data, even nine skulls were discovered, trepanated with a filing technique.

After Mokrin, a find was known from
Kriva reka, dating from the Iron Age, regarding a male skull being trepanated three times with drilling technique (Mikić 1980; Schulz 1993). After that, three trepanated skulls were discovered at Viminacium (Mikić 2006), as well as a find from the Davidovica monastery (Mikić 2000).

This is why to the trepanning phenomenon, practicated in this area for more than four millenia and belonging only to bio-physical anthropology, not much attention was paid and it is very hard to give streight answers. One should even doubt the wrongly understood work of folk doctors, which could be regarded as "out-of-fashioned and primitive"and which was to be avoided at the beginning of the 20th century.

$$
* * *
$$

This very brief overview of the history of trepanning in Europe, as well as in our region, was necessary considering the fact that the skull no. 28 from the mediaeval cemetery of Gamzigrad is the best preserved one. In comparison with other trepanated skulls from our sites, it can be said that it is fully preserved and does not require any reconstruction, which can be seen on Fig. 2/A of this paper. Fig. 2/B shows the position of the trepanning opening itself. As already stated in the abstract, its outer dimensions are $2 \times 3 \mathrm{~cm}$, immediately indicating that it is not of circular, but of irregular shape. It is situated in the middle of the left parietal bone, directly under the slightly grown parietal torus.

The inner dimensions of the trepanning opening are smaller, but very difficult to determine because of a very strong osteoplastic reaction of the bone. It led the opening itself on the utmost depth (above the dura matris) and the healing was very intensive. Therefore the author presumes that the full effect of healing of the trepanning was reached.

The difference between the dimensions of the outer and the inner trepanning openings surely indicate that it was done in filing technique, which is chronologically older. Considering the very strong osteoplastic reaction of the bone all around the trepanning opening, it cannot be determined in how many directions it was performed. One gets the impression that there were two directions. One direction was surely bowed, covering more than a 
half of the opening, and it was directed towards the lower head/skull part. The other direction of filing of the parietal bone was most likely straight, but not horizontal. It stretched diagonally from the middle of the sutura coronalis to the middle of the sutura occipitalis. Any further reconstruction of the way of opening the left parietal bone would lead to speculations, mostly because of the high level of healing. Needless to say, this man from the mediaeval Gamzigrad (Felix Romuliana) survived this very sensitive chirurgic operation, known to science as trepanning. Conclusively, it was not the causa mortis, at least not in the primary sense of diagnosis. Further on, one cannot tell whether this middle-aged man, who most likely lived in Gamzigrad during 11th century, came here with trepanning done somewhere else or did a surgeon/doctor of the time visit Gamzigrad. The only certain fact is that this is the only trepanated skull found within the mediaeval necropolis near the eastern Gamzigrad gate.

\section{BIBLIOGRAPHY}

\section{Bach, H. 1965}

Zur Berechnung der Körperhöhe aus den langen Gliedmassenknochen weiblicher Skelette, Anthrop. Anz. XXIX: 12-21.

\section{Barjaktarović, M. 1948}

O šaronjanju (trepanaciji) u Crnoj Gori, Stvaranje 11-12: 553-557.

\section{Breitinger, E. 1937}

Zur Berechnung der Körperhöhe aus den langen Gliedmassenknochen Anthrop. Anz. XIV: 249274.

\section{Broca, P. 1876}

Sur la trépanation au crane et les amulettes craniennes à l'époque néolitiques, Paris.

\section{Đorđević, V. 1883}

Die Entwicklung der öffentlichen Gesundheitspflege im serbischen Königsreiche vom XII Jahrhundert an bis 1883, Berlin.
Farkas, Gy. i Liptak, P. 1971

Antropološko istraživanje nekropole u Mokrinu, Dissertationes et Monographie XI, Beograd: Arheološko društvo Jugoslavije.

Ferembach, I. et al. 1980

Recommendations for Age and Sex Diagnoses of Skeletons, Journal of Human Evolution 9: 517549.

\section{Hein, P. 1960}

Häufigkeit, Verbreitung und Lokalisation der Schädeltreoanationen in der europäischen Vorund Frühgeschichte, Med. Diss., Berlin.

\section{Hošovski, E. i Mikić, Ž. 1995}

Paleopatologija čoveka - ilustraovana nalazima sa područja centralnog Balkana, Užice: Narodni muzej u Užicu.

\section{Iličković, M. 1940}

Prilog proučavanju istorije narodne medicine kod južnih Slovena, Biblioteka centralnog higijenskog zavoda u Beogradu XI, Beograd.

\section{Lovrinčević, A. i Mikić Ž. 1989}

Atlas of ostheopathological changes of the hystorical Yugoslav populations, Sarajevo: Svjetlost.

Martin, R. and Saller, K. 1957

Lehrbuch der Anthropologie im systematischen Darstellung I, Stuttgart: G. Fischer Verlag.

\section{Mikić, Ž. 1980}

Ilirska praistorijska lobanja iz Krive Reke u Srbiji - trepanacijski i patološki tragovi, Glasnik Antropološkog društva Jugoslavije 17: 163-170.

\section{Mikić, Ž. 2000}

O praistorijskim trepanacijama lobanja sa prostora Balkana, Antropologija bolesti $i$ zdravlja, Beograd: Srpsko antropološko društvo i Zavod za zaštitu zdravlja: 118-123.

\section{Mikić, Ž. 2006}

Trepanacija lobnja na antičkom viminacijumu antropološke informacije, Arheologija i prirodne nauke 1: 9-20. 
Mikić, Ž. 2007

Trepanacija - vek istraživanja u Srbiji, Antropologija 4: 36-47.

\section{Mikić, Ž. 2009}

The Medieval Cemetry outside the Eastern Gate of Gamzigrad / Felix Romuliana: A paleodemographic Interpretation, Balcanica XXXIX: 115121.

Nemeskéri, J. 1960

A magyarorsàgi jelképes trepanàtió, Antropológiai Közlemények IV/1-2: 3-32.

Piggot, S. 1940

A trepanned skull of the Beaker period from Dorset and the practice of trepanning in prehistoric Europe, Proceedings of the Prehistoric Society 6: 112-131.

\section{Trojanović, S. 1900}

Die Trepanationen bei den Serben - Ein anthropologischer Beitrag, Correspodenzblat der Deutschen Geselschaft für-Anthropologie, Ethnologie und Urgeschichte XXXI: 18-23.

\section{Trojanović, S. 1922}

Šaronjanje kod Srba - novi podaci, Južna Srbija - 1922: 1-7.

Schulz, M. 1993

Spuren unspezifischer Entzündungen an prähistorischen und historischen Schädeln, Anthropologische Beiträge 4/ A - B: 43-50.

\section{REZIME \\ TREPANACIJA NA \\ SREDNJOVEKOVNOM \\ GAMZIGRADU - FELIX ROMULIANA}

\section{KLJUČNE REČI: POLNA PRIPADNOST, INDIVIDUALNA STAROST, HRONOLOŠKO OPREDELJENJE, ANTROPOLOŠKE MERE, TREPANACIONA TEHNIKA, INSTRUMENTI ZA TREPANACIJU.}

Na tablama 1 i 2 date su raspoložive kranijalne i postkranijalne antropološke mere, uključujući i lobanju br. 28, koja je u celini očuvana. Paleodemografske elemente, odn. distribuciju pola i starosti donosi dijagram 1, na kome je lobanja br. 28 posebno označena. Slika 1 predstavlja plan nekropole pored istočne kapije Gamzigrada, odn. antropološku distribuciju skeleta, sa označenom lokacijom skeleta br. 28 u okviru same nekropole. Poslednji prilog - slika 2 (A + B), donosi fotografiju lobanje br. 28 sa trapanacionim otvorom. Kako je u apstraktu već navedeno, njegove spoljne dimenzije su 2 x $3 \mathrm{~cm}$, što odmah ukazuje da nuje kružnog oblika. Unutrašnje dimenzije trepanacionog otvora su manje, ali ih je vrlo teško odrediti zbog vrlo jake osteoplastične reakcije kosti, tako da se procenjuje da je ova trapanacija u celini uspela. Treba naglasiti da je ova individua sa srednjovekovnog Gamzigrada preživela i nadživela ovaj osetljiv hiruški zahvat i po kriterijumima savremene neurohirurgije. Zaključno, nije Causa mortis, bar u primarnom smislu dijagnoze. 


\section{Diagram1: Sex \& Age distribution}

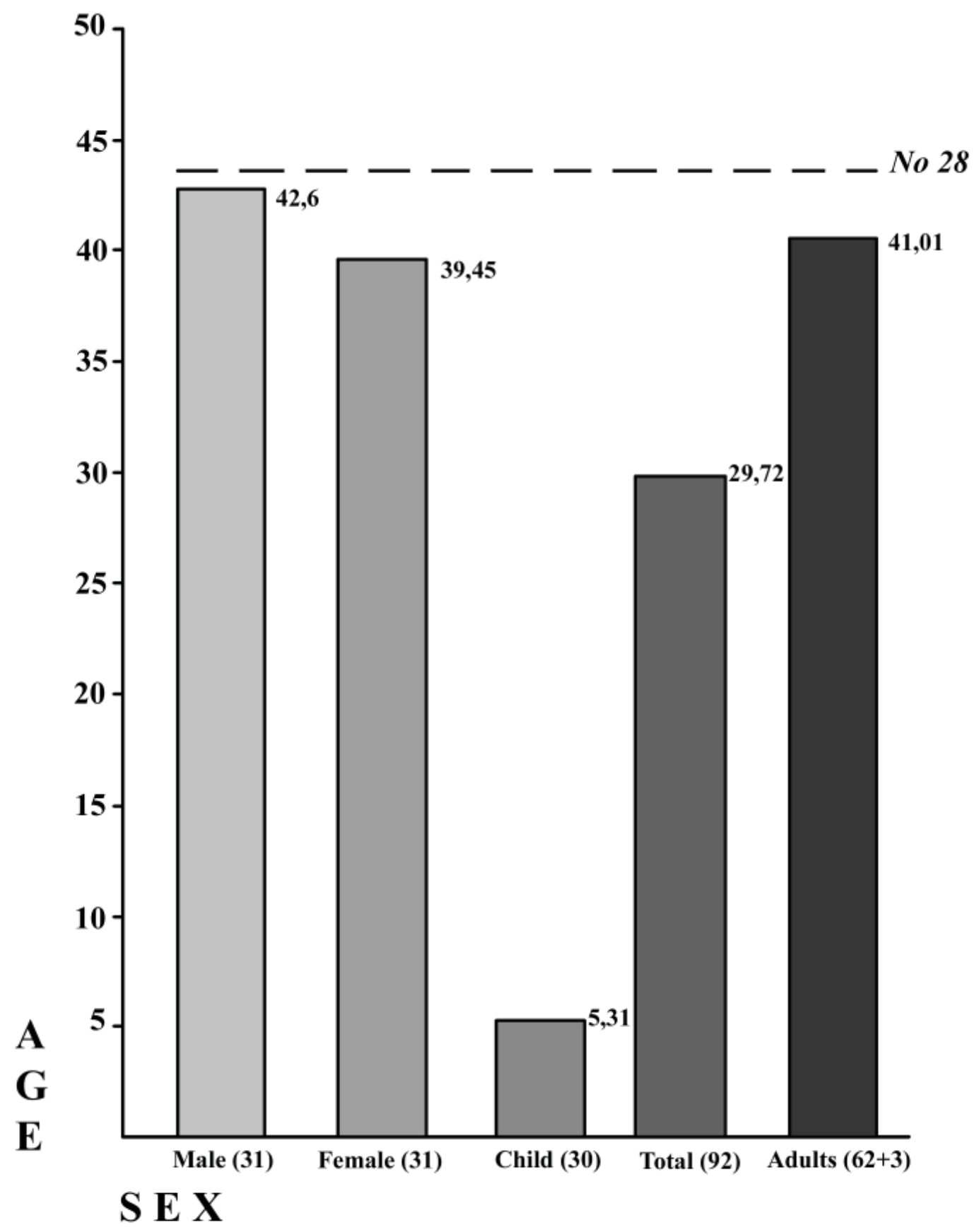




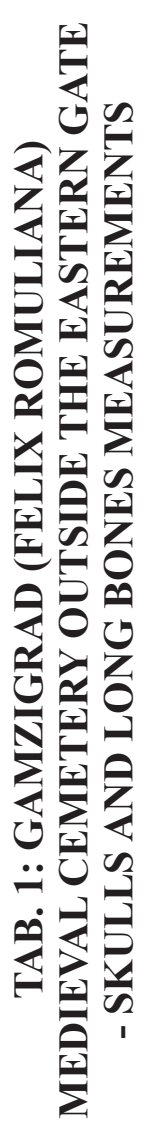

\begin{tabular}{|c|c|c|c|c|c|c|c|c|c|c|c|c|c|c|}
\hline m & 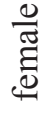 & $\stackrel{\ominus}{\text { m }}$ & $\mathscr{\infty}$ & $\stackrel{\infty}{m}$ & I & 1 & 1 & 1 & 1 & 1 & 1 & 1 & 1 & 1 \\
\hline$\vec{m}$ & $\begin{array}{l}\frac{0}{\tilde{J}} \\
\stackrel{0}{0}\end{array}$ & 으 & $\underset{1}{\infty}$ & $\bar{n}$ & $\hat{\sigma}$ & ñ & 1 & $\stackrel{0}{ }$ & $\stackrel{*}{\stackrel{*}{\sim}}$ & $\infty$ & ले & $m$ & $\vec{v}$ & $\stackrel{g}{q}$ \\
\hline
\end{tabular}

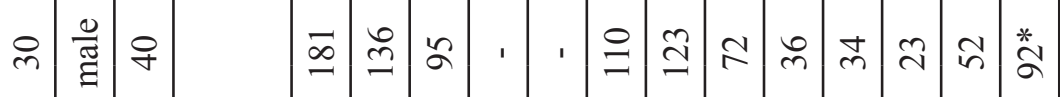

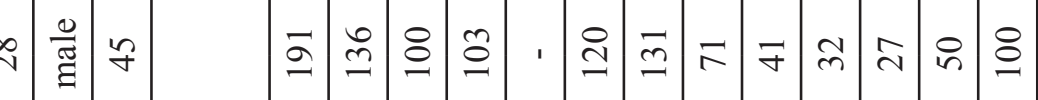

ข

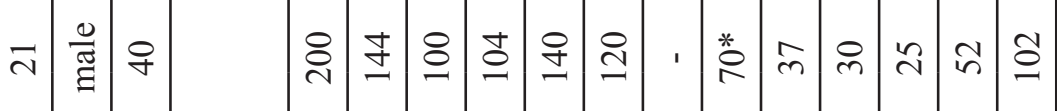

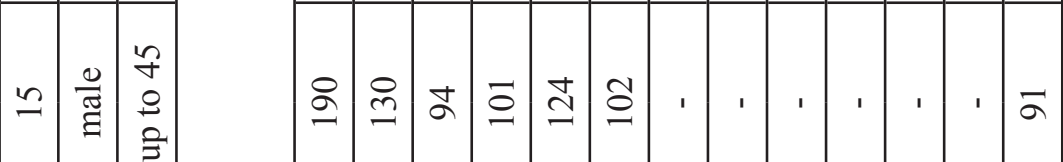

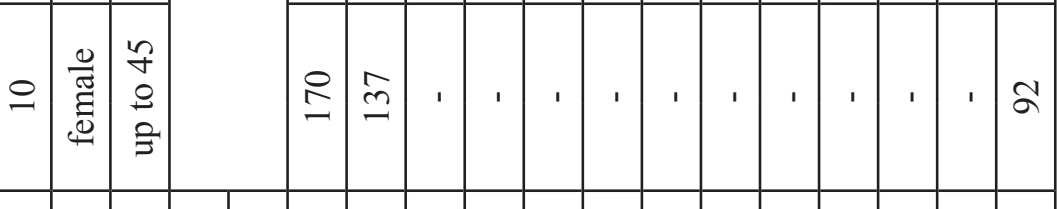

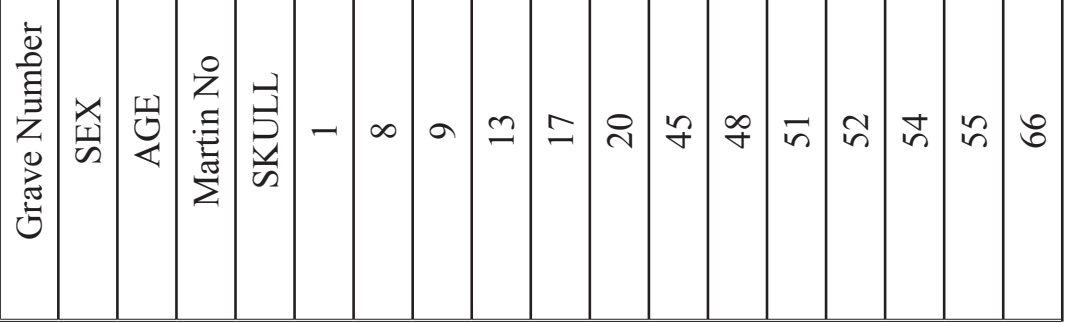




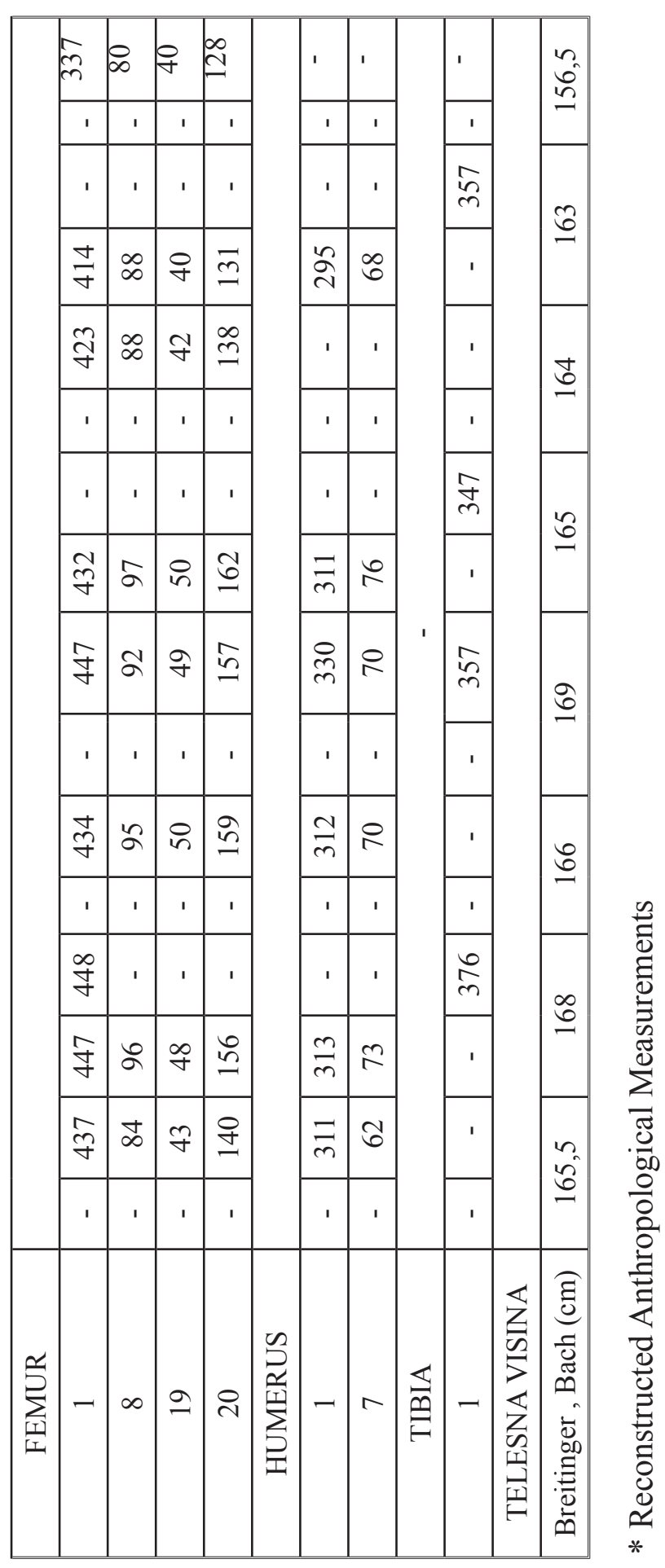



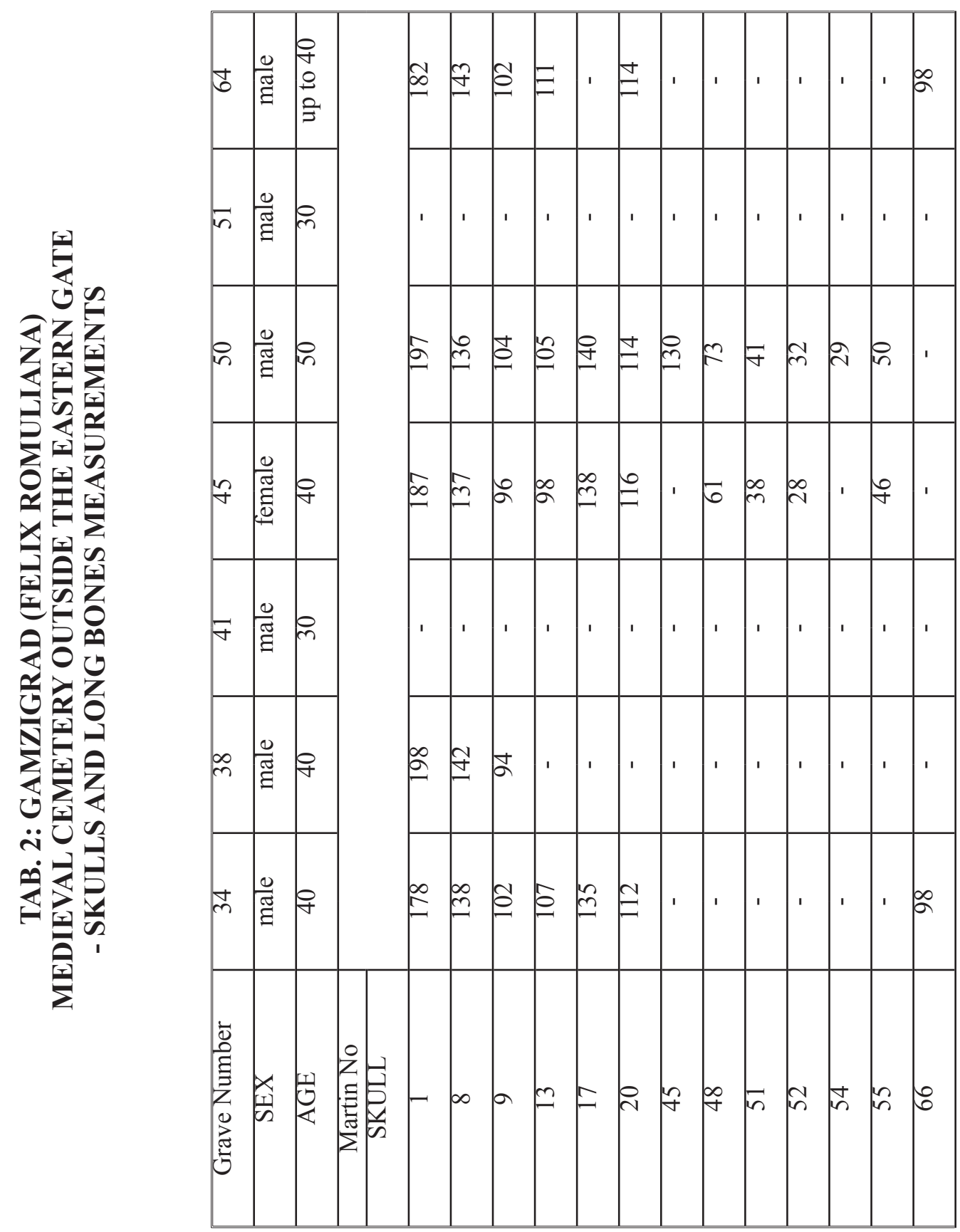


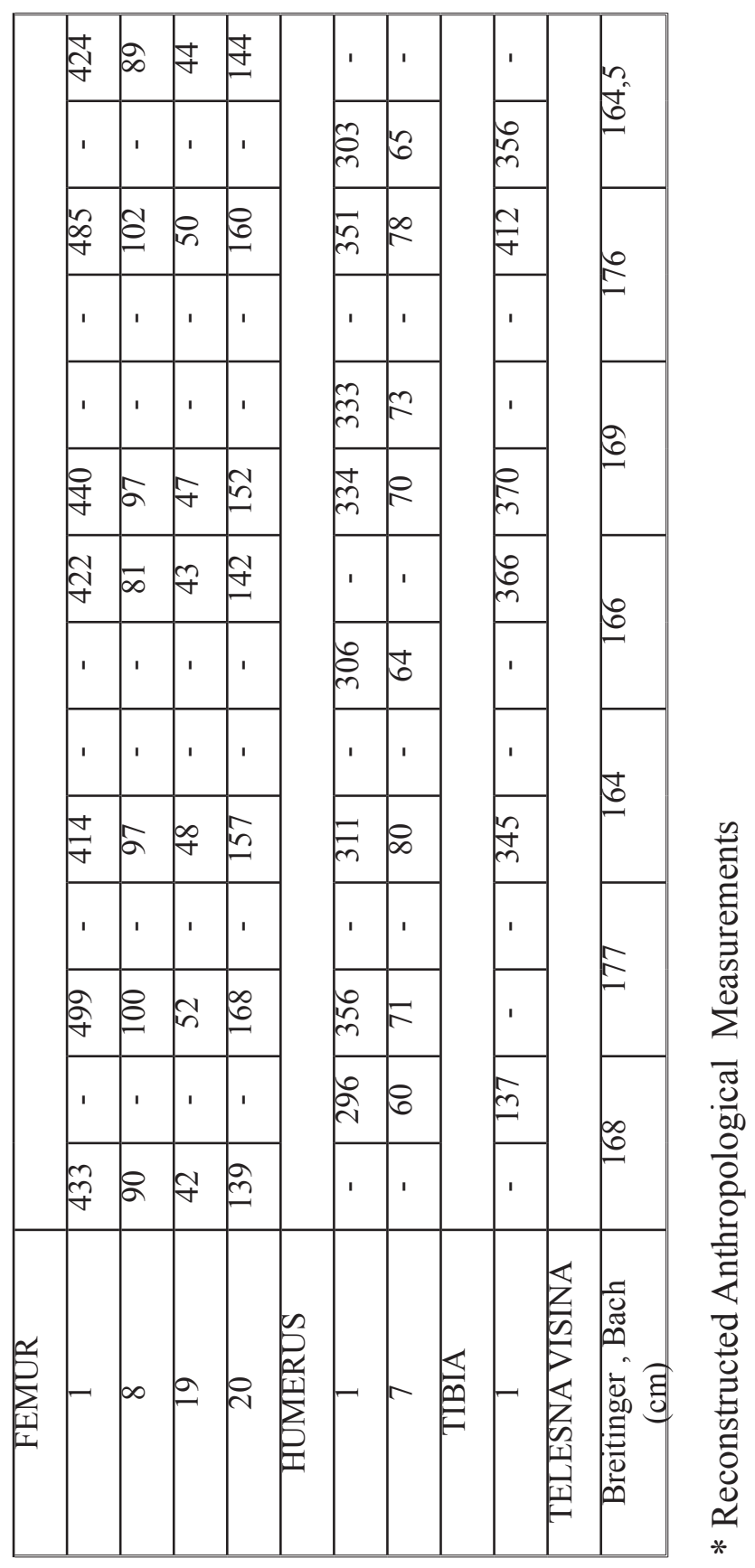



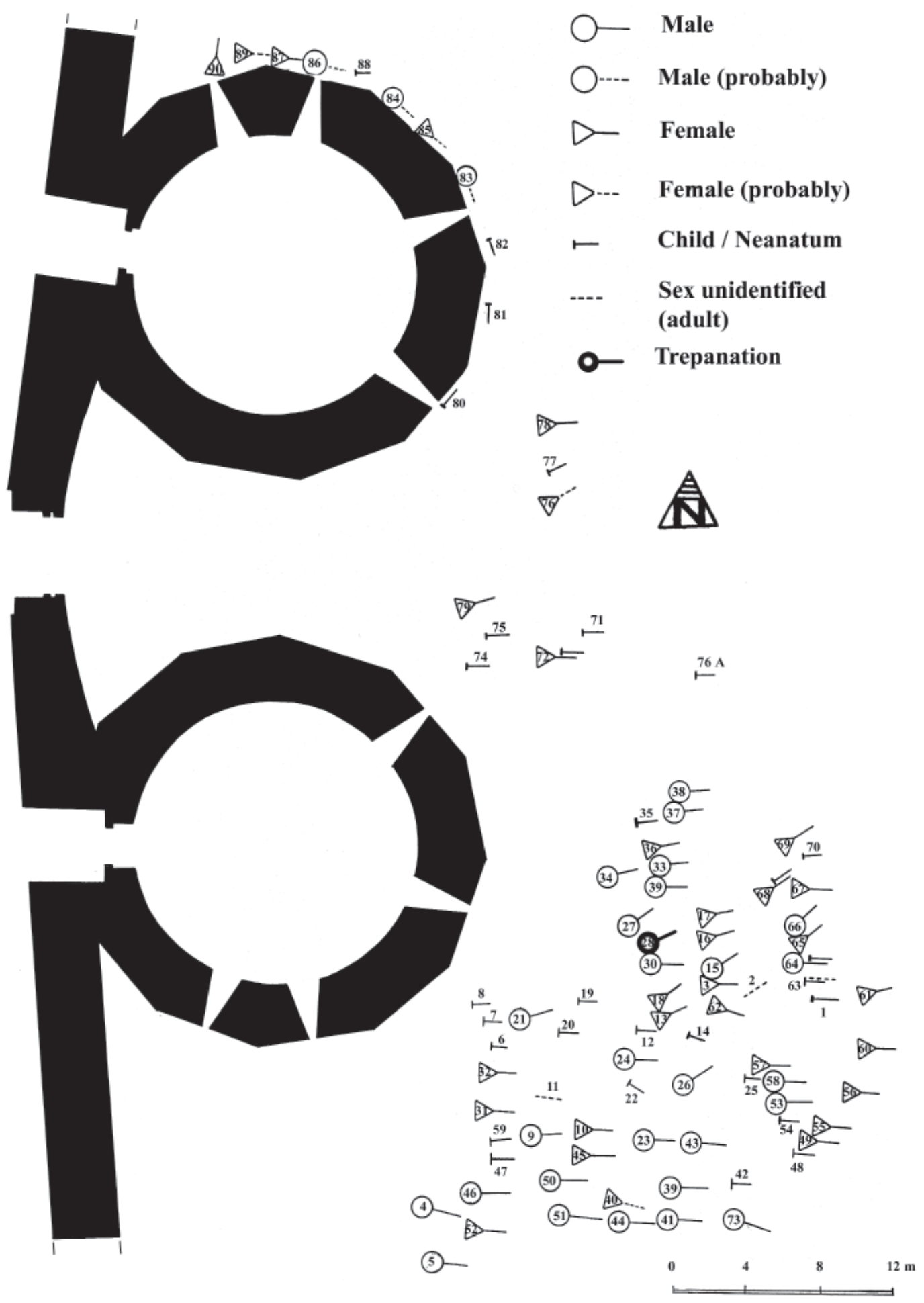

Fig l: Anthropological distribution of skeletons. 
Fig. 2: Trephinic Skull No 28;

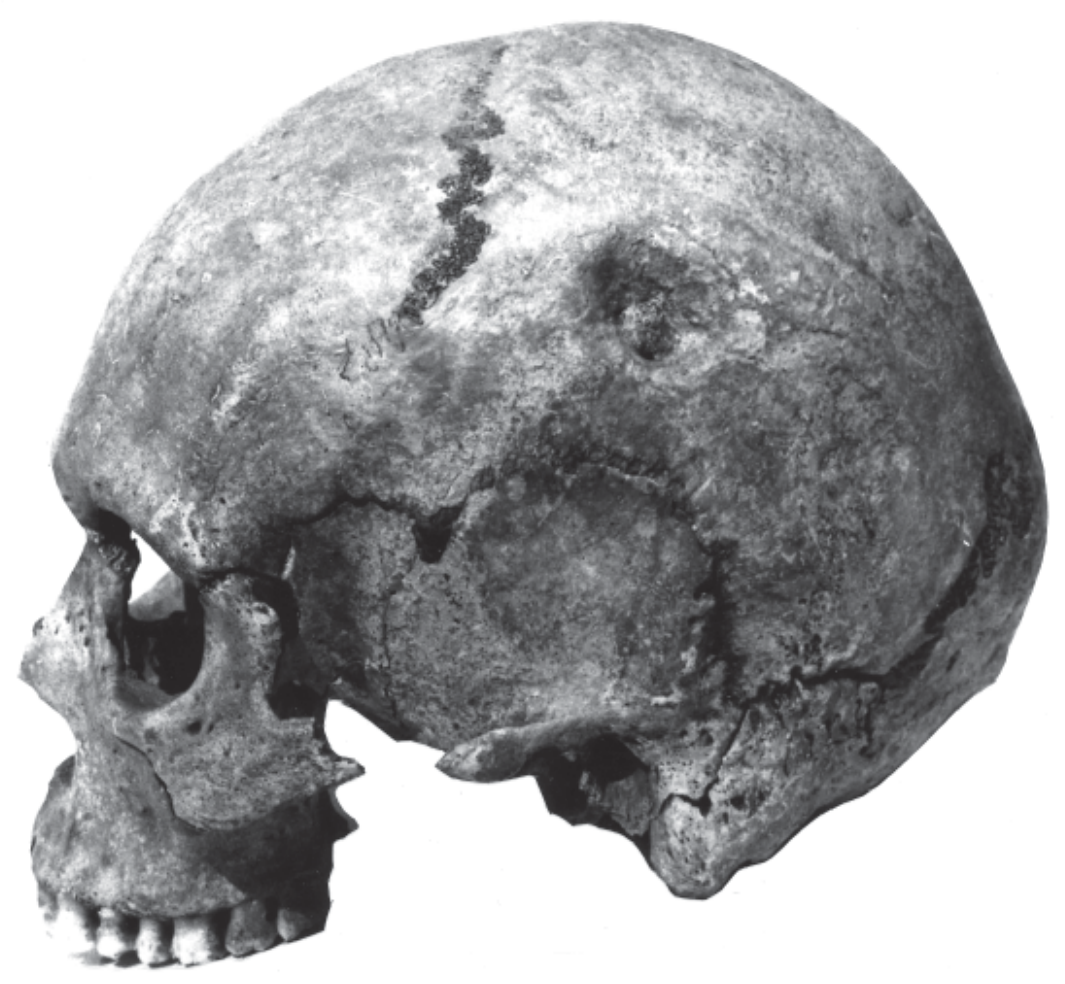

\section{A - Lateral view;}

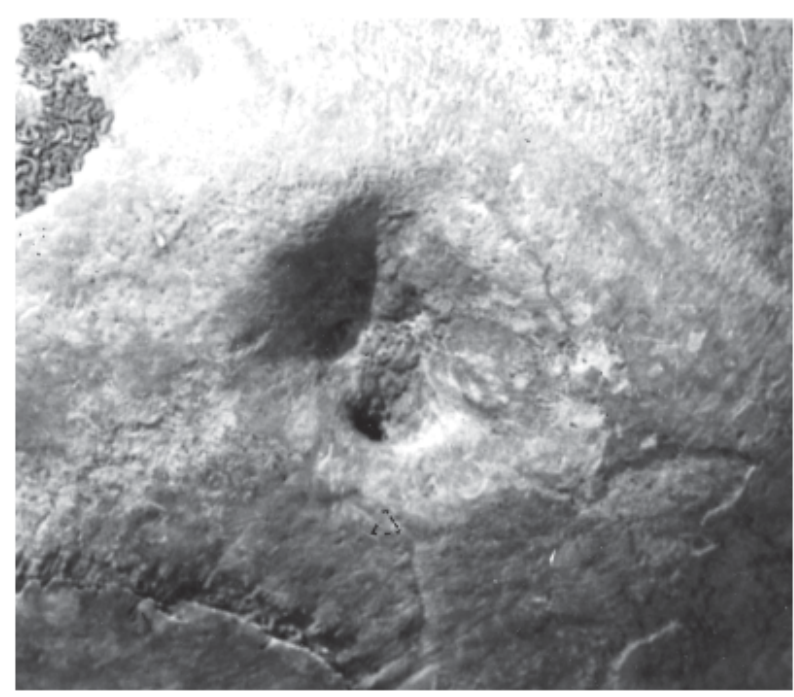

B - Part of Skull No 28 